\title{
Ecological balance: a humanitarian explication
}

\author{
Yuriy Nikiforovich Gladkiy ${ }^{1,}{ }^{*}$,and Vyacheslav Dmitrievich Sukhorukov ${ }^{2}$ \\ ${ }^{1}$ Herzen State Pedagogical University of Russia St. Petersburg, Russia \\ ${ }^{2}$ Herzen State Pedagogical University of Russia St. Petersburg, Russia
}

\begin{abstract}
The content of ecological balance is indicated as the most important factor of modern social development. The multidimensional meaning of ecological balance, which reflects the real state of naturalanthropogenic interaction, is emphasized. The economic and humanitarian content of the ecological balance is revealed.
\end{abstract}

\section{Introduction}

Among common interpretations of the stated concepts dominated the natural Sciences explanations with the "precautionary" inclusion of humanitarian components. Thus, in one case, we mean the dynamic equality of the arrival and outflow of energy, substances and information, supporting the ecosystem in a qualitatively defined state or leading to a natural change of one ecosystem to another in a series of succession development. The other implies a balance of natural or changed by man environmental components and natural processes, leading to a long (conditionally infinite) existence of the ecosystem etc. [6].

However, the balance in the system "society-nature" has a more multifaceted character and includes in its sphere the interaction of man as a biosocial being with a complex multicomponent world, with a dynamic, everincreasing habitat, the problem of preservation and promotion of health. Known, for example, the interpretation of the ecological balance under the ethnic point of view (as the preservation ethno-landscape, ethno-cultural, ethno-genetic, ethno-psychological equilibrium) and even pedagogical point of view [3; 13].

The authors-geographers understand the term "ecological balance" is a broad sense as the continuously changing relationship of geospatial objects, processes and phenomena that ensure sustainable interaction of nature and human society. The semantic content of ecological balance is based on the principles of dynamic and cyclical development of natural, anthropogenic and natural-anthropogenic systems. Therefore, the ecological balance requires a large-scale understanding, reflecting the inseparable unity of nature and man.

By the way, this unity is indicative for the so-called "deep ecology", which has acquired a wide resonance in the West today [10-15]. It is an "ecological philosophy" that promotes the self-worth of all living beings, regardless of their instrumental utility to human needs. Proponents of this scientific trend believe that the natural world is a delicate balance of complex relationships in which the existence of organisms depends on the existence of others within ecosystems. Human intervention in or destruction of the natural world poses a threat not only to human beings but also to all organisms that make up the natural order.

\section{Research methods}

The essence of ecological balance equilibrium indicates the indissoluble unity of nature and society, in which the most influential processes and circumstances of planetary reality intersect. Ecological balance can be called a necessary form of sustainable development of society and a new way of life. At the same time, ecological balance is a concern not only for the habitat, but, above all, for the person himself. Consequently, ecological balance is the integration of the natural and humanitarian sphere, as a result of which the unique vital world of people is embodied. From here, the authors have chosen an idiographic description of the value contexts of ecological balance in their unique uniqueness and phenomenological nature as the leading method of research. The holistic vision of the subject picture is also provided by the factual material of a humanitarian nature contained in the used scientific information sources.

\section{Research results}

\subsection{Environmental Code of Society}

In the dialogue sphere of nature and man the social and economic aspects are most clearly manifested. They are expressed in the resource character of economic activity and are modeled in the dynamics of the concentration of not only useful substances in the environment, but also created benefits in the social sphere. Over time, in this unity there is a constant and growing movement of resource materials in a continuously increasing and improving social product. However, if the development of society is mainly based on the growth of resource

\footnotetext{
* Corresponding author: gladky43@,rambler.ru
} 
consumption (extraction of natural resources during the XX century increased 10 times, and by 2030 it will increase twice), this type of existence should be considered non-ecological. It does not guarantee longterm progressive development, but leads to a systemic catastrophe.

The sustainable state of society can be achieved in the transition from non-ecological development to environmental, associated with reasonable, efficient and responsible management of resources. It assumes a deep greening of the industrial and social sphere, including the greening of thinking and behavior of people. Consequently, the modern socio-economic space is determined by the ecological code, reflecting the nature and dynamics of social development.

The ecological code of society, in our opinion, is a set of conceptual knowledge of both natural science and technical and humanitarian character, with the help of which the idea of the laws and mechanisms of interaction of human society with the environment is fixed. A practical embodiment of the said code should be regarded as ecological interests of the community as expressed preferences in relation to the objectives and means to sustainable and balanced development.

Ecological interests, in the end, have a focus on the preservation and enhancement of natural resources that ensure human existence. At the same time, natural resources are not only the resources of nature, but also the ability of society to provide living resources for generations of people. Natural objects and properties of space become natural wealth as they are artificially transformed into useful forces of nature, that is, into its resources. In other words, all the wealth created by nature for billions of years, is realized only as a result of painstaking human labor. The transformation of nature into wealth is achieved by huge intellectual and volitional efforts of man, so the knowledge of the natural characteristics of space should be understood and assimilated by all thinking people. "We must, first of all - wrote V.I. Vernadskiy - have knowledge of our wealth, to understand their value, to know how they should be and how can be translated into forms available for human life" $[2 ; 4 ; 8]$.

At the heart of these abilities to transform the resources of nature for the benefit of man are the humanitarian (living) forces of the people, which are determined by creative aspirations, mental and moral qualities, accumulated experience and talent. A people who are in these areas very high can achieve very much even if the natural wealth of their country is negligible.

\subsection{Natural productive forces of society}

Natural wealth, combined with the mental, strong-willed and moral character of people, form the natural productive forces of society. They, in turn, act as the main lever of the state policy on mastering the forces of nature for the arrangement of living space.

Thus, natural wealth, transformed into a national treasure, have a very capacious content and contain a certain positive meaning that meets the goals and aspirations of man. Wealth is perceived both in material form and in humanitarian terms. The dual nature of wealth emphasizes the multiple nature of human needs. They are not one natural conditionality, but also determined by social morality, cultural traditions, subjective preferences, etc. Therefore, the wealth of the country must be correlated with indicators of geosphere and humanitarian-acceptable development. Thoughtless consumer orientation to unpredictable physical and sensual pleasures without measure grinds human and natural resources and leads to irreversible consequences in the human environment.

In other words, it is not enough to have a strong socio-economic potential and material abundance. It is necessary to have own concept of use of all opportunities for the benefit of society because at preservation of humanitarian negative the fast degradation of natural resources is inevitable. The accumulation of values by any means, with the enforcement of laws justifying those methods, is unnatural. "In the art of making a fortune," Aristotle taught, "there is never a limit in achieving the goal, and the goal here is unlimited wealth and possession of money. All those engaged in monetary turnover seek to increase the amount of money indefinitely" [1]. As all further human history has shown, there are no crimes in the world that the hungry will not dare to commit in order to obtain high profits.

Consequently, the main content of social wealth should be considered the humanitarian grounds of man, expressed in his life attitudes and actions. They form the ecological strategy of the society aimed at the development of ecologically oriented economy, preservation and development of positive creative force of the people [5]. In the case of denigration of those ideals uncontrolled totalitarian power is becoming the inevitable self-sufficient value.

In other words, it is necessary to correctly understand the essence of the term "wealth" and to be aware of its root meaning. Rich is the one who appreciates the natural environment given to him, the genetic ability of its development and culture of previous generations (immaterial wealth). Modern man has gained the ability to multiply man-made landscapes, but he remains powerless to re-receive this nature. Perhaps there will come a time when humanity will realize that the true wealth that people have is natural nature. On the contrary, the immeasurable absorption of nature with inadequate morality is detrimental to humanity [9].

Russia remains among the leaders in many environmental indicators. Global ratings confirm its desire to maintain the ecosphere balance and its own ecological potential, which in the case of a balance of economic interests and environmental protection can become a driving force for the implementation of a number of economic and social projects. Meanwhile, global comparisons show that Russia lags far behind the leading countries in terms of the effectiveness of ecological development. Currently, residents of Russia use environmental resources only $60 \%$ of the national territory. But if every inhabitant of the planet led the way of life of the average Russian, humanity would need 2.5 planets to satisfy the resource appetite [7]. 


\section{Conclusion}

1. Issues of greening human society are relevant for all. They concern, above all, the greening of people's consciousness and behavior, but also targeted actions of the main actors of sustainable development - power, environmentally responsible business, environmental non-profit organizations, etc. [7].

2. In the context of the growing power of the technical capabilities of society, equilibrium and reliable humanitarian mechanisms of being are required. An indispensable role here is played by science, education, art, culture, etc.

3. To preserve the natural sphere and man in the world in modern conditions is possible only through humanitarian and political solidarity of mankind, which is complementary with nature and the planet itself. Consequently, ecological philosophy, which reflects positive knowledge about the development of nature, human society and thinking, is acquiring a high value in order to create a fundamentally new human culture and distribution mechanisms of social development.

\section{References}

[1] Aristotel Politika, M: Eksmo, 160 (2018).

[2] V.I. Vernadskii, Vopros o estestvennih proizvoditelnih silah v Rossii [Electronic resource]. Available

at: http://sinsam.kirsoft.com.ru/KSNews_38.htm (Accessed: 04.04.2019).

[3] I.Yu. Gladkii, Geograficheskie osnovi etnicheskoi ekologii, SPb.: Izd-vo LGU im. A S Pushkina, 307 (2005).

[4] Komissiya po izucheniyu estestvennih proizvoditelnih sil Rossii (KEPS) [Electronic resource]. Available at: http://www.encspb.ru/article.php (Accessed: 04.04.2019).

[5] Osnovi gosudarstvennoi politiki v oblasti ekologicheskogo razvitiya Rossii na period do 2030 goda, Utv. Prezidentom RF ot 30 aprelya 2012 g. [Electronic resource]. Available at: http_//base.garant.ru/70169264/ (Accessed: 04.04.2019).

[6] N.F. Reimers, Prirodopolzovanie, M.: Misl, 427 (1990).

[7] Rossiya v mirovom ekologicheskom prostranstve, Ejegodnik Russkogo geograficheskogo obschestva, M.: Eksmo, 40-1, 189 (2018).

[8] A.I. Subetto, Russkaya nauka: ot proshlogo - $k$ noosfernoi otvetstvennosti za buduschee Rossii $i$ chelovechestva, SPb.: Asterion, 200 (2018).

[9] A.I. Subetto, Ekologicheskii final globalnogo imperializma $i$ imperativ noosfernogo proriva chelovechestva, SPb.: Asterion, 20, 24 (2017).

[10] J.P. Clark, What Is Living In Deep Ecology?, Journal of Ecosophy, 30 (2), 157-183 (2014).

[11] A. Drengson, B. Devall, M. Schroll, The Deep Ecology Movement: Origins, Development, And
Future Prospects, International Journal of Transpersonal Studies, 30, 1/2, 101-117 (2011).

[12] H. Kopnina, If A Tree Falls And Everybody Hears The Sound: Teaching Deep Ecology To Business Students, Journal of Education for Sustainable Development, 9, 1, 101-116 (2015).

[13] A. Misiaszek, G. William, Ecopedagogy and Citizenship in the Age of Globalisation: connections between environmental and global citizenship education to save the planet, European Journal of Education, 50, 3, 280-292 (2015).

[14] G. Sessions, Deep Ecology, New Conservation, And The Anthropocene Worldview, Journal of Ecosophy, 30, 2, 106-114 (2014).

[15] M. Smith, Deep Ecology: What Is Said And (To Be) Done, Journal of Ecosophy, 30, 2, 141-156 (2014). 